\title{
New record of an economic marine alga, Ahnfeltiopsis concinna, in Korea
}

\author{
Pil Joon Kang and Ki Wan Nam * (D)
}

\begin{abstract}
An economic marine alga, which is considered to be an important source of carrageenan, was collected from Jindo of the southern coast of Korea. This species shares the vegetative and female reproductive features of Ahnfeltiopsis and is characterized mostly by its small size (up to $8 \mathrm{~cm}$ ), terete to subterete thalli at the lower portion, cartilaginous in texture, dichotomous branches, rarely produced proliferations, and an absence of hypha-like filaments in the medulla. It is distinguished from other Korean species within the genus by the thallus feature. In a phylogenetic tree based on the molecular data, this alga nests in the same clade with A. concinna from Japan but forms a sister clade to $A$. concinna from Mexico and Hawaii (type locality). However, the genetic distance among those sequences was calculated as 0.1-1. $3 \%$ for rbcL and $1.1 \%$ for $\mathrm{COI}$ sequences, considered to be intraspecific variation within the genus. Based on the morphology and molecular analysis, this alga is identified as A. concinna originally described from Hawaii. This is the first record of the species in the Korean marine algal flora.
\end{abstract}

Keywords: Ahnfeltiopsis concinna, Korea, Economic marine alga, Molecular analysis, rbcL, COI, Morphology, First record

\section{Background}

Ahnfeltiopsis P.C. Silva et DeCew belongs to Gigartinales F. Schmitz, which is considered to be one of the economic marine algal taxa as an important source of carrageenan (Craigie 1990; Donald et al. 1993). Particularly, it has been known that this alga can be used as a potential commercial material of antioxidant compounds in the medicine, food, pharmaceutical, and cosmetic industries in Hawaii (Kelman et al. 2012).

This genus was first proposed by Silva and DeCew in Silva (1979), but was invalid. Later, the generic name, Ahnfeltiopsis, was validly published. It was characterized by internal cystocarps and a heteromorphic type of life history in which upright unisexual gametophytes alternate with a crustose tetrasporophyte (Silva and DeCew 1992; Masuda 1993). However, it has been reported that Ahnfeltiopsis is polyphyletic in molecular phylogeny (Fredericq and Lopez-Bautista 2002; Maggs et al. 2013; Calderon and Boo 2016; Calderon et al. 2016; the present study). This suggests that the generic features should be revised for delimitation of Ahnfeltiopsis.

\footnotetext{
* Correspondence: kwnam@pknu.ac.kr

Department of Marine Biology, Pukyong National University, Busan 48513, South Korea
}

(c) The Author(s). 2017 Open Access This article is distributed under the terms of the Creative Commons Attribution 4.0 International License (http://creativecommons.org/licenses/by/4.0/), which permits unrestricted use, distribution, and reproduction in any medium, provided you give appropriate credit to the original author(s) and the source, provide a link to the Creative Commons license, and indicate if changes were made. The Creative Commons Public Domain Dedication waiver (http://creativecommons.org/publicdomain/zero/1.0/) applies to the data made available in this article, unless otherwise stated.
Ahnfeltiopsis involves 33 species distributed from temperate to tropical waters (Dawson 1954; Masuda 1993; Silva et al. 1996; Guiry and Guiry 2017). Among these, three species, Ahnfeltiopsis catenata (Yendo) Masuda, A. paradoxa (Suringar) Masuda, and A. flabelliformis (Harvey) Masuda, had been reported in Korea (Kim et al. 2013). However, recently, the former two species have been transferred to Besa Setchell based on molecular and morphological examination (Calderon et al. 2016). Accordingly, only A. flabelliformis in this genus is currently recorded in the Korean marine algal flora. A gigartinalean species was collected from Jindo of the southern coast of Korea during a survey of marine algal flora. Based on the morphology and molecular data, this species was identified as Ahnfeltiopsis concinna, which was established from Hawaii (Dawson 1961), and is newly recorded in Korea in the present study.

\section{Methods}

Specimens for this study were collected from Jindo located in southern coast of Korea. Taxonomic data were obtained from fresh, liquid-preserved, and herbarium specimens. Liquid-preserved material was stored in a $10 \%$ solution of formalin/seawater. For anatomical 
observations, the material was cleared in $5-10 \% \mathrm{NaOH}$ in distilled water for 2-7 days and then rinsed in distilled water. Blades dissected from the cleared materials were hand sectioned, transferred to a slide with a drop of distilled water, and mounted in pure glycerin. In some instances, a smearing method for microscopic examination was employed. Measurements are given as width and length. For photographs, the sections were stained with $0.5-1.0 \%$ aqueous methylene blue, aniline blue, or hematoxylin. For permanent slides, the glycerin was exchanged with $10-20 \%$ corn syrup.

Total genomic DNA was extracted from silica-gelpreserved sample using the DNeasy Plant Mini Kit (Qiagen, Hilden, Germany) according to the manufacturer's protocol. Before extraction, dried material was crushed with liquid nitrogen using a mortar and pestle. Concentrations of extracted DNA were assessed by using gel electrophoresis on a 1\% agarose gel. Extracted DNA was used for amplification of ribulose-1, 5-bisphosphate carboxylase/oxygenase large subunit $(r b c \mathrm{~L})$ regions and cytochrome oxidase I (COI). PCR amplifications were performed in a TaKaRa PCR Thermal Cycler Dice (TaKaRa Bio Inc., Otsu, Japan). The PCR products were moved to Macrogen Sequencing Service for sequencing (Macrogen, Seoul, Korea). The sequences of PCR primers for amplification are as follows: $r b c \mathrm{~L}$ (forward: 5' GGAG GATTAGGGTCCGATTCC 3', reverse: 5' CTTCCGTCA ATTCCTTTAAG 3'), COI (forward: 5' GCTGCGTTCT TCATCGATGC 3', reverse: $5^{\prime}$ TCCTCCGCTTATTGA TATGC 3') (Lin et al. 2001).

Sequences for the $r b c \mathrm{~L}$ region were aligned using BioEdit (Hall 1999). Phylogenetic analyses were performed using neighbor joining, maximum-likelihood, and maximum parsimony methods with Mega 6 program (Tamura et al. 2013). Bootstrap values were calculated with 1000 replications. $\mathrm{R} b c \mathrm{~L}$ and COI sequences of other species were obtained from GenBank. Ahnfeltia plicata was used as an outgroup.

\section{Results and discussion}

Ahnfeltiopsis concinna (J. Agardh) P.C. Silva \& DeCew 1992: 577

Type locality: Hawaii (Dawson 1961)

Korean name: Go-un-bu-chaet-sal nom. nov. (신칭: 고 운부챗살)

Specimens examined: NIRBAL0000146348, PKNU 0000127011 - 0000127015 , PKNU 0000127025 (Jindo: 13.ii.2014)

Habitat: Growing on rock near upper to lower intertidal

Morphology: Thalli 5-8 cm high, terete to subterete at the lower portion, somewhat compressed at the upper portion, fan-shaped, brown to yellow in color, cartilaginous in texture, attached to substratum by discoid holdfast (Fig. 1 and Fig. 2a); main axes issuing dichotomous

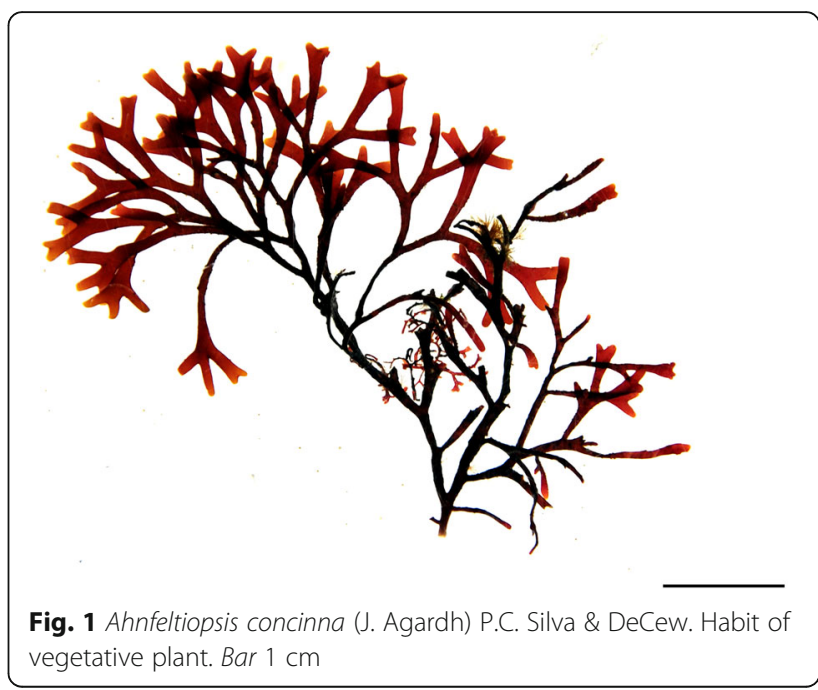

branches at short intervals; branches divided dichotomously to subdichotomously, with rounded or blunt apex, 1-2 mm wide, 200-300 $\mu \mathrm{m}$ thick; proliferations rare, arranged pinnately to irregularly; multiaxial; cortex consisted with small and pigmented cells (Fig. 2c, d), five to eight round cell layers thick, $2-3 \times 4-5 \mu \mathrm{m}$; pseudoparenchymatous medulla compact (Fig. 2a), ellipsoid in transverse section (Fig. 2b), without hypha-like filaments, 200-300 × 80-100 $\mu \mathrm{m}$; gonimoblast filaments developing inwardly (Fig. 3a, b), carposporophytes producing masses of carposporangia; carposporangia round (Fig. 3c), 10$12 \mu \mathrm{m}$ in diam.; cystocarps formed at middle portion of branches, internally immersed in medulla, surrounded by some layers of secondary medullary cells, with carpostomes (Fig. 3c, d). Male and tetrasporangial plants were not collected during the present study.

Ahnfeltiopsis was established to accommodate several species, which had been previously assigned to Ahnfeltia E.M. Fries and Gymnogongrus C. Martius (Silva and DeCew 1992) and which have common internal cystocarps with specialized pores (carpostomes) and crustose tetrasporic life history (Silva and DeCew 1992; Masuda 1993). However, since the genus is known to be polyphyletic based on molecular data (Fredericq and Lopez-Bautista 2002; Maggs et al. 2013; Calderon and Boo 2016; Calderon et al. 2016; the present study), the generic delimitation cannot be used for Ahnfeltiopsis. Recently, some combined features of female structures have been adopted for this genus (Calderon and Boo 2016; Calderon et al. 2016). The vegetative feature of multiaxial thalli with a compact and pseudoparenchymatous medulla is also common in the genus (Masuda 1993). Even though male and tetrasporangial plants were not observed, our gigartinalean species collected from Jindo, Korea, during this study can be referred to Ahnfeltiopsis based on these vegetative and female features in addition to the 

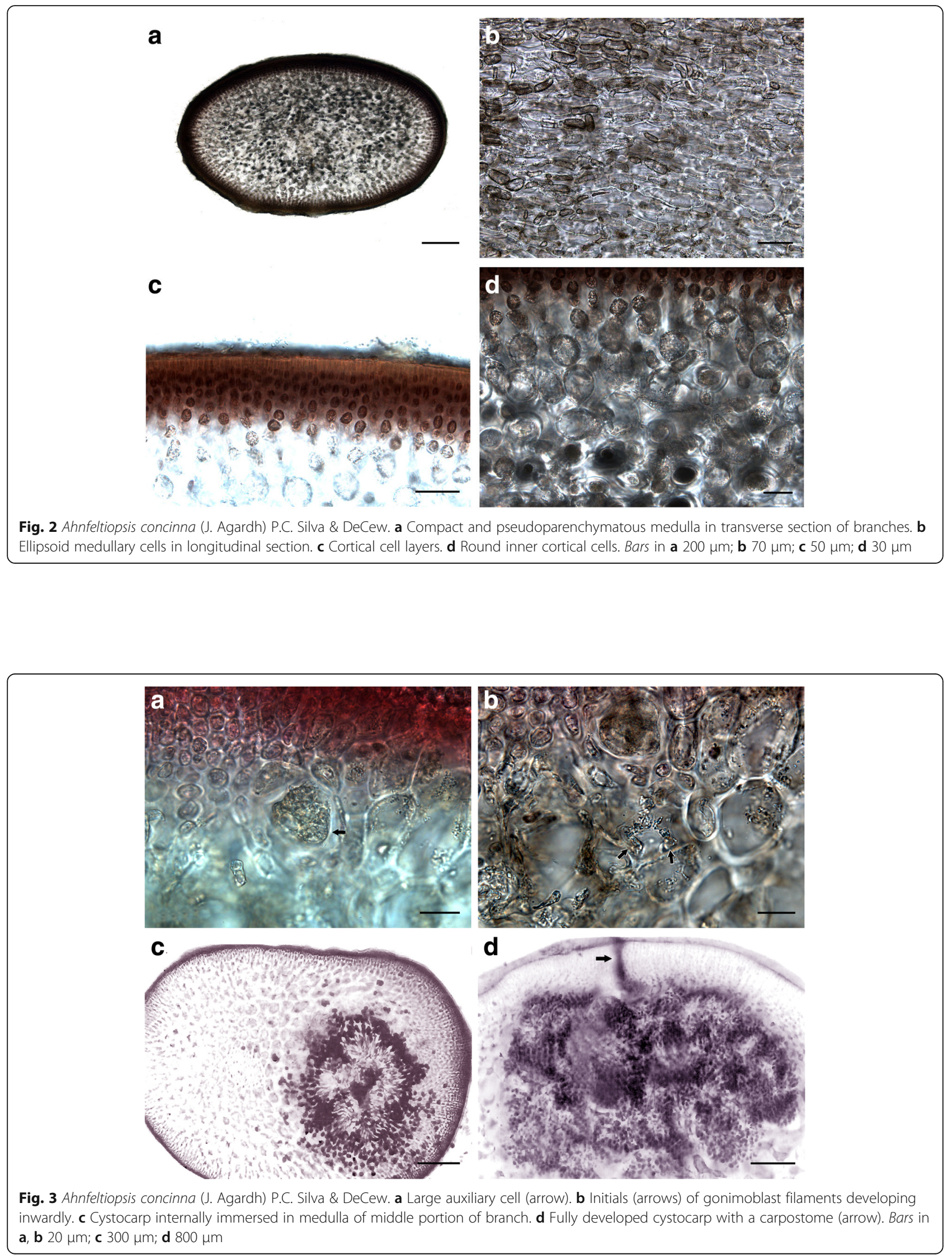


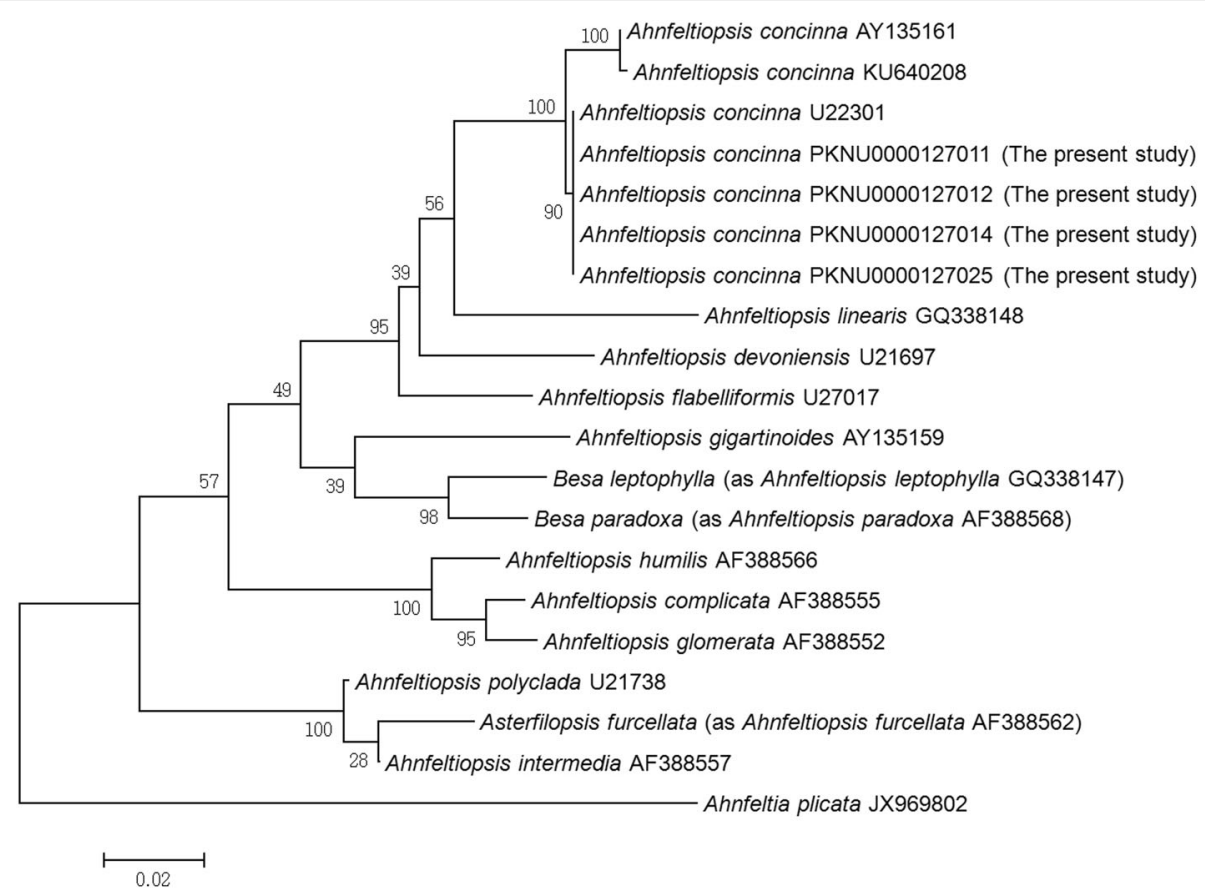

Fig. 4 Phylogenetic tree of Ahnfeltiopsis species obtained from maximum likelihood method based on rbcL sequences. Bootstrap proportion values (1000 replicates samples) are shown above branches. Bar indicates 0.02 substitutions/site

gross morphology. According to the original and other publications (Silva and DeCew 1992; Masuda et al. 1994; Braune and Guiry 2011), Ahnfeltiopsis concinna is distinct from similar species within the genus by its small size (up to $8 \mathrm{~cm}$ ) thalli, terete to subterete thalli, cartilaginous in texture, dichotomous branches, rarely produced proliferations, and an absence of hypha-like filament in the medulla. This Korean alga shares these characteristics and is distinguished from A. flabelliformis which is currently recorded in Korea (Kang 1966, 1968; Lee and Kang 1986; Lee and Kang 2002; Boo and Ko 2012; Kim et al. 2013), by the thallus feature. It has terete to subterete thalli particularly at the lower portion, while A. flabelliformis shows compressed thalli (Masuda 1987, 1993; Masuda et al. 1994; Yoshida 1998; Lee 2008).

In a phylogenetic tree based on $r b c \mathrm{~L}$ sequence data (Fig. 4), the Korean alga nests in the same clade with $A$. concinna from Japan but forms a sister clade to $A$. concinna from Mexico and Hawaii (type locality). However, the genetic distance among those sequences was calculated as $0.1-1.3 \%$, considered to be intraspecific variation within the genus. In general, the value of

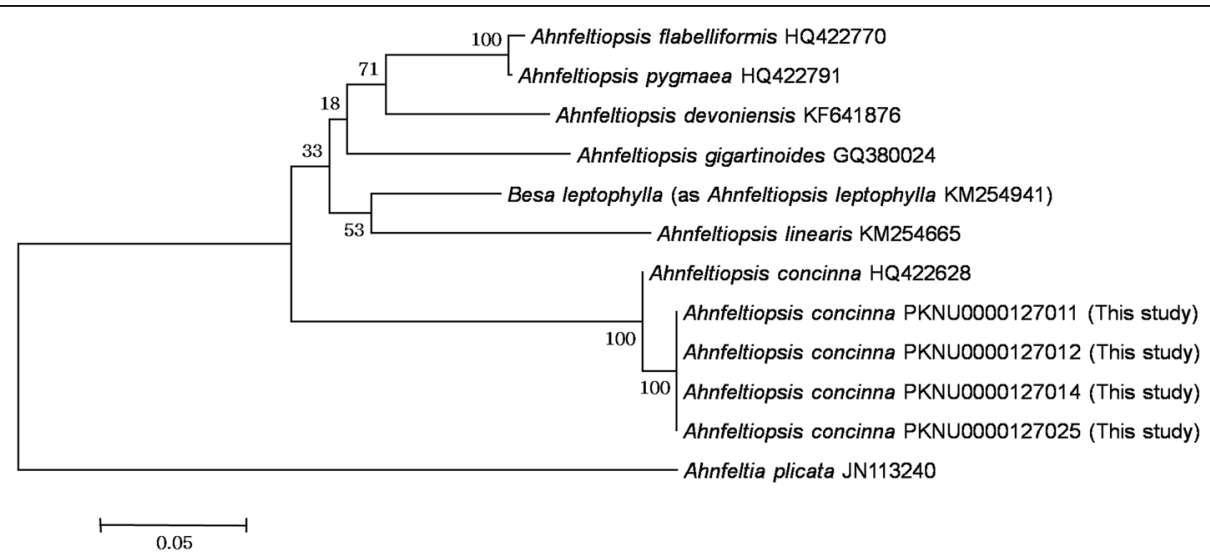

Fig. 5 Phylogenetic tree of Ahnfeltiopsis species obtained from maximum likelihood method based on COI sequences. Bootstrap proportion values (1000 replicates samples) are shown above branches. Bar indicates 0.05 substitutions/site 
interspecific divergence in the Gigartinaceae and Peyssonneliaceae within the Gigartinales varies from 2.8 to 16.5\% (Hommersand et al. 1994; Kato et al. 2009). Moreover, the Korean alga also nests in the same clade with A. concinna from the type locality based on the COI sequence data (Fig. 5), with the genetic distance of $1.1 \%$ between the two sequences.

This morphological and molecular evidence leads to the conclusion that our specimens from Jindo, Korea, should be identified as Ahnfeltiopsis concinna originally described from Hawaii. This species is newly recorded in Korea in the present study.

\section{Conclusions}

A gigartinalean species was collected from Jindo, Korea, during a survey of marine algal flora. This species was identified as Ahnfeltiopsis concinna, which was originally described from Hawaii, based on morphological and molecular data. This is the first record of the species in the Korean marine algal flora.

\section{Abbreviations}

COI: Cytochrome C oxidase subunit 1; rbcL: ribulose-1, 5-bisphosphate carboxylase large subunit

\section{Funding}

This work was supported by a grant from the National Institute of Biological Resources funded by the Ministry of Environment (MOE) of the Republic of Korea (NIBR201701204), and by a grant from Marine Biotechnology Program (20170431) funded by the Ministry of Oceans and Fisheries of the Korean Government.

\section{Availability of data and materials}

All datasets analyzed during the current study are available from the corresponding author on reasonable request.

\section{Authors' contributions}

PJK conducted the research, analyzed the materials, and prepared the draft manuscript. KWN designed and directed the study and finalized the manuscript. Both authors read and approved the final manuscript.

\section{Ethics approval and consent to participate}

Not applicable.

\section{Consent for publication}

Not applicable.

\section{Competing interests}

The authors declare that they have no competing interests.

\section{Publisher's Note}

Springer Nature remains neutral with regard to jurisdictional claims in published maps and institutional affiliations.

Received: 17 May 2017 Accepted: 26 September 2017

Published online: 13 October 2017

\section{References}

Boo SM, Ko YD. Marine plants from Korea. Seoul: Marine \& Extreme Genome Research Centre Program; 2012.

Braune W, Guiry MD. Seaweeds. A color guide to common benthic green, brown and red algae of the world's oceans. Ruggell: A.R.G. Gantner Verlag K.G; 2011.
Calderon MS, Boo SM. Phylogeny of Phyllophoraceae (Rhodophyta, Gigartinales) reveals Asterfilopsis gen. nov. from the Southern Hemisphere. Phycologia. 2016;55(5):543-54.

Calderon MS, Miller KA, Seo TH, Boo SM. Transfer of selected Ahnfeltiopsis (Phyllophoraceae, Rhodophyta) species to the genus Besa and description of Schottera koreana sp. nov. Eur J Phycol. 2016;51(4):431-43.

Craigie JS. Cell walls. In: Cole KM, Sheath RG, editors. Biology of the red algae. New York: Cambridge University Press; 1990. p. 221-58.

Dawson EY. Marine plants in the vicinity of the Institute Oc'eanographique de Nha Trang. Vietnam Pac Sci. 1954;8:372-469.

Dawson EY. Marine red algae of Pacific Mexico. Part 4. Gigartinales Pac Nat. 1961;2:191-343.

Donald FK, Dutcher JA, Bird KT, Capecchi MF. Nuclear genome characterization and carrageenan analysis of Gymnogongrus griffithsiae (Rhodophyta) from North Carolina. J Appl Phycol. 1993:5:99-107.

Frederica S, Lopez-Bautista JM. Characterization and phylogenetic position of the red alga Besa papillaeformis Setchell: An example of progenetic heterochrony? Constancea. 2002;83(9):1-12.

Guiry MD, Guiry GM. AlgaeBase. World-wide electronic publication, National University of Ireland, Galway. 2017. http://www.algaebase.org. Accessed 6 Mar 2017.

Hall TA. BioEdit: a user-friendly biological sequence alignment editor and analysis program for Windows 95/98/NT. Nucleic Acids Symp Ser. 1999;41:95-8.

Hommersand MH, Frederica S, Freshwater DW. Phylogenetic systematics and biogeography of the Gigartinaceae (Gigartinales, Rhodophyta) based on sequence analysis of rbcL. Bot Mar. 1994;37:193-203.

Kang JW. On the geographical distribution of marine algae in Korea. Bull Pusan Fish Coll. 1966;7:1-125.

Kang JW. Illustrated encyclopedia of fauna and flora of Korea, Vol.8. Marine algae. Seoul: Samhwapress; 1968.

Kato A, Guimarães SMPB, Kawai H, Masuda M. Characterization of the crustose red alga Peyssonnelia japonica (Rhodophyta, Gigartinales) and its taxonomic relationship with Peyssonnelia boudouresquei based on morphological and molecular data. Phycol Res. 2009;57:74-86.

Kelman D, Posner EK, McDermid KJ, Tabandera NK, Wright PR, Wright AD Antioxidant activity of Hawaiian marine algae. Mar Drugs. 2012;10:403-16.

Kim HS, Boo SM, Lee IK, Sohn CH. National List of Species of Korea 「Marine Algae」. Seoul: Jeonghaengsa; 2013.

Lee Y. Marine algae of Jeju. Seoul: Academy Publication; 2008.

Lee IK, Kang JW. A check list of marine algae in Korea. Kor J Phycol. 1986;1:311-25.

Lee Y, Kang SY. A catalogue of the seaweeds in Korea. Jeju: Jeju National University Press; 2002

Lin S-M, Frederucq S, Hommersand MH. Systematics of the Delesseriaceae (Ceramiales, Rhodophyta) based on large subunit rDNA and rbcL sequences, including the Phycodryoideae, subfam. nov. J Phycol. 2001;37:881-99.

Maggs CA, Le Gall L, Mineur F, Provan J, Saunders GW. Fredericaia deveauniensis, gen. et sp. nov. (Phyllophoraceae, Rhodophyta), a new cryptogenic species. Cryptogam Algol. 2013;34:273-96.

Masuda M. Taxonomic notes on the Japanese species of Gymnogongrus (Phyllophoraceae, Rhodophyta). J Fac Sci Hokkaido Univ, Series V (Botany). 1987;14:39-72

Masuda M. Ahnfeltiopsis (Gigartinales, Rhodophyta) in the western Pacific. Jap J Phycol. 1993;41:1-6.

Masuda M, Zhang JF, Xia BM. Ahnfeltiopsis from the western Pacific: key, description and distribution of the species. In: Abbott IA, editor. Taxonomy of economic seaweeds, vol. 4. California: A Publication of the California Sea Grant College; 1994. p. 159-83.

Silva PC. The benthic algal flora of central San Francisco Bay. In: Conomos TJ, editor. San Francisco Bay: The urbanized estuary. San Francisco: Pac Div Amer Ass Adv Sci; 1979. p. 287-345

Silva PC, Basson PW, Moe RL. Catalogue of the benthic marine algae of the Indian Ocean. Univ Calif Publ Bot. 1996;79:1-1259.

Silva PC, DeCew TC. Ahnfeltiopsis, a new genus in the Phyllophoraceae (Gigartinales, Rhodophyceae). Phycologia. 1992;31:576-80.

Tamura K, Stecher G, Peterson D, Filipski A, Kumar S. MEGA6: Molecular Evolutionary Genetics Analysis version 6.0. Mol Biol Evol. 2013;30:2725-9.

Yoshida T. Marine algae of Japan. Tokyo: Uchida Rokakuho Publishing; 1998. 